Outros Tempos, vol. 10, n.16, 2013 p. 229-255. ISSN:1808-8031

\title{
A DITADURA BRASILEIRA E O GOLPE DE ESTADO CHILENO
}

\section{THE BRAZILIAN DICTATORSHIP AND THE CHILEAN COUP D'ETAT}

\section{LA DICTADURA BRASILEÑA Y EL GOLPE DE ESTADO DE CHILE}

\author{
ENRIQUE SERRA PADRÓS \\ Professor do Departamento de História e dos PPG em História \\ e Relações Internacionais da UFRGS \\ Porto Alegre/ RS/Brasil \\ lola@adufrgs.ufrgs.br \\ SÍLVIA SIMÕES \\ Mestre em História pela UFRGS \\ Porto Alegre/ RS/Brasil \\ ssimoesbr@yahoo.com.br
}

\begin{abstract}
Resumo: O artigo propõe resgatar o acompanhamento da ditadura brasileira sobre os acontecimentos relacionados com o golpe de Estado que derrubou o presidente chileno Salvador Allende. Para tal procura identificar, além da percepção conjuntural do governo brasileiro sobre a região, certos fatores do processo que relacionou as ditaduras do Chile e Brasil, particularmente: a) a questão do monitoramento e vigilância sobre o universo dos exilados brasileiros; b) a atuação da embaixada brasileira nos eventos prévios ao 11 de setembro de 1973 e o grau de envolvimento com os setores golpistas.
\end{abstract}

Palavras-chave: Ditadura Brasileira e o Cone Sul. Ditadura Brasileira e o Golpe contra Allende. Ditadura Pinochet.

\begin{abstract}
This paper aims to show the monitoring of the Brazilian dictatorship over the events related to the coup d'etat that overthrew Chilean President Salvador Allende. For this, it seeks to identify, beyond the conjunctural perception of the Brazilian government on the region, certain factors of the process related to dictatorships of Chile and Brazil, particularly: a) the issue of monitoring and surveillance on the universe of Brazilian exiled people b) the procedure of the Brazilian embassy in the events preceding September 11, 1973 and their level of involvement with the coup participants.
\end{abstract}

Keywords: Brazilian Dictatorship and Southern Cone. Brazilian Dictatorship and the coup d'etat against Allende. Pinochet Dictatorship.

Resumen: El artículo propone rescatar el acompañamiento de la dictadura brasileña sobre los ocurridos relacionados con el golpe de Estado que derrotó el presidente de Chile, Salvador Allende. Para eso, se identifica, además de la percepción conjetural del gobierno brasileño sobre la región, ciertos factores del proceso que relacionó las dictaduras de Chile y Brasil, particularmente: a. vigilancia sobre el universo de los exilados brasileños; b. actuación de la embajada brasileña en los eventos previos al 11 de septiembre de 1973 y el grado de envolvimiento con los sectores golpistas.

Palabras clave: Dictadura Brasileña. Cone Sur. Dictadura Brasileña. Allende. Dictadura Pinochet.

\section{Introdução}

Este artigo tem como proposta resgatar o acompanhamento da ditadura brasileira sobre os acontecimentos relacionados com o golpe de Estado que derrubou o presidente Salvador Allende. Nesse momento, o Chile era o país que mais exilados brasileiros havia

\footnotetext{
${ }^{1}$ Artigo submetido à avaliação em 01/08/2013 e aprovado para publicação em 15/10 /2013.
} 
recebido, fato este que, em si, gerava receios no governo de Emílio Garrastazu Médici. Desde o início dos anos 1970, o Brasil jogava importante rol na definição geopolítica do Cone Sul. Além de observar o desdobramento dos eventos chilenos, havia colaborado com a queda do general Juan José Torres, na Bolívia; aprofundado relações com a ditadura de Alfredo Stroessner; pressionado ameaçadoramente a deteriorada democracia uruguaia; e, em 1973, avaliou com preocupação a instalação do governo de Héctor Cámpora na Argentina. Dentro de tal marco, o texto pretende identificar, ademais da percepção conjuntural do governo brasileiro sobre a região, certos fatores do processo que relacionou as ditaduras do Chile e Brasil, particularmente: a) a questão do monitoramento e vigilância sobre o universo dos exilados brasileiros; b) a atuação da embaixada brasileira nos eventos prévios ao dia 11 de setembro de 973 e o grau de envolvimento com os setores golpistas. As fontes para este texto compreendem documentação produzida pelo regime repressivo brasileiro, documentos desclassificados estadunidenses, crônica jornalística e bibliografia especializada. Apesar de certo caráter exploratório, o texto procura contribuir com o esforço de apontar as formas de colaboração entre as diversas Ditaduras de Segurança Nacional da região, ainda antes do Plano Condor, e a compreensão do papel articulador que o Brasil desempenhou em tal processo.

\section{Brasil pós-64: olhando para a região... E agindo.}

No Brasil, desde que se instalou a Ditadura de Segurança Nacional, as autoridades desenvolveram dois grandes eixos de preocupações imediatas. Por um lado, tudo o que dizia respeito ao combate interno contra qualquer foco de questionamento à nova ordem instituída, portanto, a necessidade de enquadrar/eliminar os setores considerados "subversivos", "comunistas" ou "terroristas" através da Operação Limpeza e das demais práticas repressivas desencadeadas como políticas de Estado - condição fundamental para realizar a profunda reestruturação capitalista que orientava a iniciativa dos setores golpistas civis e militares. Por outro lado, desde uma perspectiva geopolítica, aguçar um olhar sobre a América Latina sobrepondo e/ou combinando critérios de segurança nacional interna - a disseminação dos seus exilados pela região -, e externa - a preocupação com governos, organizações armadas, políticas ou sociais vizinhas, hostis aos seus interesses -, com uma perspectiva de agressiva pretensão hegemônica, embora sempre mascarada com posturas defensivas inseridas na lógica maior das diretrizes gerais da Guerra Fria. Nesse sentido, não se pode esquecer os postulados apontados por Golbery de Couto e Silva, em 1967, na sua “Geopolítica do Brasil”, em relação às ameaças que a América Latina sofria naquele contexto: 
[...] o certo é que a probabilidade maior parece de fato apresentar, hoje, a guerra limitada, o conflito localizado e, sobretudo, a agressão comunista indireta que capitaliza os descontentamentos locais, as frustrações da miséria e da fome, os justos anseios nacionalistas, os ressentimentos e ódios anticolonialistas gerados por um longo passado de opressão imperialista, para, insuflando-os, apoiando-os até mesmo materialmente, provocar a erupção de violentos focos de perturbação e desordem e ganhar, afinal, decisiva influência, senão desde logo o domínio ostensivo, seja através de golpes de Estado desfechados por uma camarilha que se lhe dobre às imposições, seja mediante uma longa e exaustiva guerra subversiva de terrorismo e de guerrilhas. ${ }^{2}$

Como se vê, há uma clara alusão à expansão continental da ameaça da guerra revolucionária e uma lúcida percepção de que ela é fomentada por bases materiais bem concretas, como a fome, a desigualdade social, a herança colonialista ou os efeitos do imperialismo. Mas Golbery vislumbra um problema maior do que a multiplicação de focos guerrilheiros:

[...] a América do Sul realmente se encontra sob ameaças muito palpáveis que, a qualquer tempo, podem vir a concretizar-se em surtos insurrecionais, objetivando, embora não declaradamente, a implantação, em território sul-americano, de um governo favorável à ideologia comunista e que se constitua em grave e urgente perigo à unidade e segurança das Américas e de todo o mundo ocidental [...]. [Devemos] prepararmo-nos, na América Latina, para dar a mão a qualquer de nossos vizinhos, na defesa de um inigualável patrimônio comum, contra quaisquer investidas exóticas. ${ }^{3}$

A possibilidade de uma nova Cuba no sul do continente é claramente aventada por Golbery e, diante disso, o Brasil deveria estar vigilante. Sendo assim, pode-se inferir o impacto produzido no interior do centro do poder da ditadura brasileira com a vitória eleitoral da Unidad Popular (UP), no Chile, em setembro de 1970. Mas o que deve ter desnorteado os prognósticos de Brasília foi que a chegada de Salvador Allende ao governo não resultou de uma guerra irregular ou da ação de organizações "subversivas", mas do exercício democrático, fator destacado pelos defensores do mundo ocidental em contraposição ao totalitarismo do mundo comunista. De qualquer forma, a liderança brasileira reagiu rápido: se não conseguiu agir com rapidez em relação ao Chile, se mobilizou rapidamente para evitar que pudesse ocorrer a mesma coisa, um ano depois, no Uruguai (Operação 30 Horas).

A influência e intervenção crescente da ditadura brasileira na esfera da política interna de diversos países da região é fato reconhecido na crônica jornalística da época. Tal fato vem sendo corroborado nos documentos produzidos pela própria estrutura burocrática do Estado brasileiro, e que, aos poucos, ganham luz para ajudar a definir melhor o que foram as

\footnotetext{
${ }^{2}$ SILVA, Golbery do Couto e. Conjuntura política nacional: o poder executivo e geopolítica do Brasil. 3 ed. Rio de Janeiro: J. Olympio, 1981. p. 193.

${ }^{3}$ Ibid., p. 193-194.
} 
relações binacionais e internacionais durante o período prévio e a instalação do conjunto de Ditaduras de Segurança Nacional ao longo do Cone Sul. Efetivamente, o Brasil passou a desempenhar uma política de colaboração ativa com setores mobilizados na defesa do status quo vigente e contra qualquer proposição de reformas ou mudanças estruturais. Na prática, apoiou o advento de regimes securitistas que ajudassem tanto a estabilizar a região, como a combater o que era percebido como ameaça comunista a escala continental. A deterioração das condições de vida da maior parte da população latino-americana, acompanhada de altos índices de desigualdade social, se combinou com o impacto produzido pelos ecos da revolução Cubana. Em decorrência disso, o crescimento dos protestos, da organização social dos setores mais pobres e das propostas de esquerda, em países como Chile, Bolívia, Uruguai e Peru, entre outros, não passou despercebido aos generais brasileiros e seus sócios internos e externos, particularmente as corporações multinacionais, o capital financeiro e os Estados Unidos.

Nesse sentido, os anos 1960 constituíram um período no qual as questões internas de segurança (e seus desdobramentos externos) ganharam prioridade. A iniciativa brasileira de pressionar o governo democrático uruguaio, desde que lá se instalou a comunidade exilada em 1964, deve ser vista desde essa perspectiva; ou seja, a presença e o ativismo político de parte do governo de João Goulart, bem como de centenas de seus simpatizantes em Montevidéu, tornou essa questão um tema de segurança nacional para o governo brasileiro. Para parte do sistema político uruguaio, o uso de mecanismos de chantagem política, econômica, diplomática e até ameaças militares por parte da potência vizinha, se configurou como intromissão nas questões internas do país, ou seja, como um verdadeiro ataque à sua soberania nacional. ${ }^{4}$

A ditadura brasileira foi deixando rastros na sua participação e colaboração com as políticas de controle regionais, como demonstram Boccia, González e Palau ao analisarem um documento de 1968 que explicita a vinculação entre as polícias paraguaia e brasileira em ações de planificação de segurança e tarefas clandestinas e encobertas:

Asunción, 23 de agosto de 1968

Al contestar

Cítese N. J-751

ASUNTO: INFORME CONFIDENCIAL N. 751

\footnotetext{
${ }^{4}$ Ver para esta discussão: PADRÓS, Enrique Serra. Como el Uruguay no hay... terror de estado e segurança nacional: Uruguai (1968-1985): do Pachecato à ditadura civil-militar. 2 v. Tese (Doutorado em História). Porto Alegre: UFRGS, 2005. FERNANDES, Ananda Simões. Quando o inimigo ultrapassa a fronteira: as conexões repressivas entre a ditadura civil-militar brasileira e o Uruguai (1964-1973). Dissertação (Mestrado em História). Porto Alegre: UFRGS, 2009.
} 


\author{
AL: SEÑOR JEFE DEL II DPTO. INVESTIGACIONES \\ TRANSCRIPCIÓN DEL INFORME ELEVADO A ESTA JEFATURA POR EL \\ VICE CONSUL DEL PARAGUAY EN SAO PAULO (Brs)
}

\begin{abstract}
"São Paulo, 20 de agosto de 1968. C.G.P. Que el día de ayer la dirección del Departamento de Orden Público y Social de Sao Paulo (DOPS), nos comunicó que obran en su poder documentos de una red de guerrilleros que actúan entre Asunción y Sã. [sic] La Dirección del Departamento de Orden Público y Social solicitó la intervención de un elemento de la Policía de Asunción, para que viaje a ésta y pueda obtener informaciones.

Aprovecho la oportunidad para saludarle con mi consideración distinguida. (Fdo Vice Cónsul)"

Se servirá adoptar las medidas que el caso requiere.
\end{abstract}

JEFE DE POLICIA ${ }^{5}$

Os autores, que se debruçaram sobre os documentos do denominado "Arquivo do Terror" do Paraguai, afirmam, ainda, que o formato dos informes de inteligência paraguaios dos anos 1970 era idêntico ao do Serviço Nacional de Informações (SNI) brasileiro. Tal afirmação indica que o intercâmbio de experiências discricionárias e de controle também ocorria no âmbito da produção de informação. ${ }^{6}$

Patrice McSherry informa que após a derrubada do presidente João Goulart, o Brasil se tornou importante base contrarrevolucionária e aliado estratégico da política dos Estados Unidos (EUA) na região, capacitando militares de outros países em cursos de ação contra guerrilheira, técnicas de interrogatório e métodos de repressão. ${ }^{7}$ Além de dar apoio permanente à ditadura do Paraguai, as ações mais ousadas do Brasil nesse período foram a participação no golpe de Estado que derrubou o governo do general Juan José Torres, na Bolívia, e a preparação do plano para invadir o Uruguai - denominado Operação 30 Horas $^{8}$ caso ocorresse a possibilidade de uma vitória eleitoral da Frente Ampla no processo eleitoral de 1971. É importante salientar que, nessas iniciativas, o Brasil agia em consonância com os interesses dos EUA. Efetivamente, Henry Kissinger, em nome do presidente Richard Nixon, havia informado ao general e ditador Emílio Médici que "Em esferas de mútuo interesse, como é o caso das situações do Uruguai e da Bolívia, a estreita colaboração e nossos enfoques paralelos podem ser muito úteis para obter nossos objetivos comuns". 9

\footnotetext{
5 BOCCIA PAZ, Alfredo; GONZÁLEZ, Myrian; PALAU, Rosa. Es mi informe: los archivos secretos de la policía de Stroessner. Asunción: Centro de Documentación y Estudios; Servilibro, 2006. p. 282.

${ }^{6}$ Ibid., p. 308.

${ }^{7}$ McSHERRY, J. Patrice. Los Estados depredadores: la Operación Cóndor y la guerra encubierta en América Latina. Montevideo: Banda Oriental, 2009. p. 96.

8 PADRÓS, Enrique Serra. "A ditadura brasileira de Segurança Nacional e a Operação 30 horas: intervencionismo ou neocisplatinização do Uruguai?" Ciências \& Letras, n. 37, Porto Alegre, jan./jun. 2005, p. 227-249.

9 "Secret Memorandum from Kissinger on his conversation with Brazilian President on December 8", 10 dec. 1971, citado por McSHERRY, op. cit., nota 179. p. 101.
} 
Na prática, Kissinger defendia que a ditadura do Brasil assumisse um papel especial no hemisfério, sempre e quanto o fizesse como representante dos interesses dos EUA. ${ }^{10}$ Nessa posição, ele estava perfeitamente sintonizado com o presidente Nixon, que explicitava o desejo de que Médici “estivesse a cargo de todo o continente". ${ }^{11}$ De fato, essas conversações são hoje bem conhecidas; em 2009, a organização não governamental estadunidense National Security Archive (NSA) tornou públicos documentos relacionados às conversações entre Nixon e Médici, em dezembro de 1971, para derrubar o governo da Unidad Popular. ${ }^{12}$ Durante as mesmas, Nixon fez alusão direta à questão central que vinculava o Cone Sul com a lógica da Guerra Fria, e que delegava à ditadura brasileira papel central: "Estados Unidos e Brasil devem prever novos Allendes e Castros e tentar reverter essas tendências onde seja possível”, acrescentando que o Brasil, enquanto país sulamericano, "podia fazer muitas coisas que os Estados Unidos não podiam fazer na região".13 Portanto, poucos anos após o diagnóstico de Golbery do Couto e Silva, explicitava-se a ação de vigilância atenta e urgente na região, e o implemento de iniciativas que permitissem intervir e reverter tendências políticas não desejadas em andamento.

Em meados de 1971, os regimes de Salvador Allende (Chile), Juan José Torres (Bolívia) e Juan Velasco Alvarado (Peru), dentro da lógica da Doutrina de Segurança Nacional (DSN), eram considerados "comunistas"; na melhor das hipóteses, hostis aos interesses ocidentais. Nesse contexto, a ditadura brasileira passou a desenvolver uma percepção geopolítica de ameaça de cerco "comunista” em expansão pelo sul do continente e, ameaçadoramente, sobre suas fronteiras. Em função disso, se aproximou cada vez mais dos setores anticomunistas dos países vizinhos, assim como procurou estar permanentemente próxima da filosofia securitista da política externa dos EUA - independente de certas divergências no campo econômico e político.

Antecipando-se a essa perspectiva, um editorial de "O Estado de São Paulo", de 14 de janeiro de 1971, havia gerado mal-estar e polêmica na região. O Uruguai era o alvo central do artigo, mas não era o único país tido como ameaçado:

\footnotetext{
${ }_{11}^{10}$ McSHERRY, op. cit., p. 101.

11 "Conversações de Nixon com o secretário de Estado Wiliam Rogers", 7 dec. 1971, citado por McSHERRY, op. cit., nota 63. p. 62.

${ }^{12}$ Segundo a documentação publicitada pelo NSA, Nixon teria consultado Médici para saber se os militares chilenos tinham poder suficiente para derrubar Allende. Médici teria contestado que sim, e acrescentou algo muito importante: "Brasil estava trabalhando nesse objetivo". "Nuevos datos sobre la conspiración contra Salvador Allende". Disponível em: http://salvadorallende.blog.lemonde.fr/2009/08/18/. Acesso em: 30 nov. 2013.

${ }^{13} \mathrm{Na}$ ocasião, foram indicados como interlocutores dessas orientações sigilosas o ministro de Relações Exteriores Mário Gibson Barbosa, pelo Brasil, e Henry Kissinger, pelos EUA. Ibid.
} 
O que ocorreu no Uruguai não é apenas um assunto interno desse pequeno país encravado entre duas grandes potências da América Latina, o Brasil e a Argentina. Dentro dos quadros continentais e hemisféricos, o que ali ocorre afeta a segurança nacional dos seus vizinhos. [Note-se aqui como se assume o discurso da geopolítica e da DSN]. É natural, pois, que os governos responsáveis e as opiniões públicas dos países latino-americanos mais diretamente interessados acompanhem com crescente preocupação a crise uruguaia, que hoje está praticamente institucionalizada [...]. ${ }^{14}$

O jornal refere-se aos acontecimentos envolvendo o aumento da escalada tupamara e a instabilidade da situação interna do Uruguai, apesar do governo autoritário de Jorge Pacheco Areco. Cabe lembrar que o sequestro, em Montevidéu, do cônsul brasileiro Aloysio Dias Gomide, em 1970, que ficou meses na mão da guerrilha, concentrou a atenção do Brasil para os acontecimentos internos daquele país. O conturbado clima eleitoral oriental aumentava as incertezas. O editorial do "Estadão" - um dos mais influentes jornais brasileiros - continua em uma linha cada vez mais ameaçadora:

[...] não nos achamos em condições de dormir tranqüilos, pois, se não podem ser melhores as relações entre os governos argentino, paraguaio, uruguaio e brasileiro, a verdade é que OS ACONTECIMENTOS DO URUGUAI AMEAÇAM COLOCARNOS, DE UM MOMENTO PARA OUTRO, DIANTE DE UMA SITUAÇÃO PERFEITAMENTE IDÊNTICA ÀQUELA QUE EM 1851 FORÇOU O BRASIL A TRANSPOR AS FRONTEIRAS DO SUL PARA QUE A REPÚBLICA ORIENTAL NÃO FOSSE ABSORVIDA E INTEGRADA NA ARGENTINA DE ROSAS. [grifo de Paulo Schilling]

O problema, hoje, no Uruguai, como também, em graus variados, o de outros tantos países da América Latina, é o desafio representado pela subversão do comunismo internacional. No País Oriental, nos meados da década de 1960, tentou-se aplicar a receita da "revolução de cima", segundo o modelo janguista. [Curiosa vinculação com a experiência do governo Goulart.] Hoje, há dois grupos totalitários que tentam conquistar o poder: os tupamaros anarquizantes de inspiração castrista e "MIR"-ista, que empregam os métodos terroristas, e o da Unidade Popular, que pretende repetir o êxito de sua homônima chilena. Enquanto os tupamaros visam solapar as instituições antes modelarmente democráticas do Uruguai, [...] forma-se uma agremiação de "frente popular" à imagem e à semelhança da frente popular atualmente no poder no Chile, a qual pretende chegar ao poder, no Uruguai pela via eleitoral, nas eleições marcadas para o fim deste ano. ${ }^{15}$

O texto explicita duplamente o caso chileno, não só a relação dos tupamaros com o Movimiento de Izquierda Revolucionaria (MIR), como na própria inspiração de uma frente eleitoral de esquerda. Sem dúvida, o paradigma da "via chilena ao socialismo" inspira temor nos setores dominantes brasileiros:

[...] a Unidade Popular oferece a possibilidade da tomada do poder pela via

\footnotetext{
${ }^{14}$ Editorial do Estado de São Paulo, 14 dez. 1971, apud SCHILLING, Paulo. O expansionismo brasileiro. São Paulo: Global, 1981. p. 13.

${ }^{15}$ Ibid., p. 14.
} 
parlamentar, pois os comunistas ortodoxos da linha moscovita julgam que o Uruguai é um dos poucos lugares da América Latina nos quais a experiência do Chile pode ser repetida [...]. A campanha eleitoral promete ser particularmente violenta, com ameaça de guerra civil, que foi o grande argumento dos partidários de Salvador Allende antes do pleito presidencial no Chile.

O Pacto Andino, originalmente um tratado de mercado comum sub-regional, está recebendo uma conotação ideológica, podendo, portanto, intensificar perigosamente a guerra fria na América Latina. A progressiva comunização da Bolívia [referência ao governo de centro-esquerda do general Torres] e a crescente insegurança no Uruguai são novas ameaças diante das quais a diplomacia brasileira terá de se mobilizar. ${ }^{16}$

A agressividade contida na leitura de conjuntura realizada pelo meio de comunicação está em sintonia com a postura do governo brasileiro. Sinais claros de alerta são enviados ao Uruguai e à Bolívia e, indiretamente, ao Chile socialista, visto como modelo ou foco de tensões regionais.

O desenvolvimento da conjuntura regional mostrará a escalada da desestabilização contra os governos de esquerda ou progressistas, em benefício dos projetos ancorados na DSN. Assim, em agosto de 1971, o general Torres foi derrubado da presidência boliviana, com apoio explícito do regime brasileiro. ${ }^{17}$ A queda deste mandatário era desejada pelo Brasil, que, por isso, auxiliou a burguesia de Santa Cruz de la Sierra, epicentro do movimento golpista liderado pelo general Hugo Banzer. O Brasil deslocou tropas até essa fronteira, permitindo a passagem de armas e aguardando o desfecho dos acontecimentos; uma das alternativas vislumbradas, em caso de indefinição dos acontecimentos, consistia no apoio a um movimento separatista liderado por Santa Cruz de la Sierra. ${ }^{18}$ A partir do desfecho dos acontecimentos na Bolívia e da consolidação da ditadura de Banzer, a Bolívia passou a receber inúmeros investimentos brasileiros, o que a tornou refém das pretensões hegemônicas do Brasil.

O passo seguinte para os interesses do Brasil era resolver o impasse interno uruguaio, gerador de incertezas e ameaças, sobretudo sobre a sensível fronteira sul do Brasil. Desde o semanário Marcha Paulo Schilling anunciava que: "El éxito de la 'operación Bolivia' constituye a la vez un estímulo para nuevos avances. Después del derrocamiento de Torres, el blanco principal pasó a ser el Uruguay". ${ }^{19}$ Schilling embasava tal afirmação na análise de

\footnotetext{
${ }^{16}$ SCHILLING, op. cit., p. 15.

17 "El golpe de Bolivia, financiado, planeado y orquestado por la diplomacia y los servicios secretos brasileños, constituye una prueba fehaciente de que los militares de derecha brasileños ya pasaron de la teoría a la práctica". SCHILLING, Paulo. “irá Brasil a la guerra?” Marcha, 26 nov. 1971, p. 22. Aviões brasileiros levaram a Santa Cruz armamento, munição, assessores e tropas rebeldes bolivianas. O Brasil também deu apoio econômico, político e diplomático aos setores golpistas. Dias antes da deflagração do golpe de Estado, as filiais do Banco do Brasil em La Paz e Santa Cruz repartiam publicidade com consignas políticas favoráveis ao movimento rebelde. Ver: CASTRO MARTÍNEZ, Pedro Fernando. Fronteras abiertas: expansionismo y geopolítica en el Brasil contemporáneo. México: Siglo XXI, 1980. p. 143.

${ }^{18}$ Ibid.

${ }^{19}$ Ibid., p. 22.
} 
alguns editoriais e manchetes dos principais veículos de comunicação brasileira, fortemente alinhados à orientação intervencionista, como o já citado editorial de "O Estado de São Paulo" ou o do jornal "O Globo": "En el póquer de la subversión latinoamericana, Bolivia acaba de liberarse del castro-comunismo. Uruguay, mientras tanto parece dispuesto a candidatarse para ocupar su puesto". ${ }^{20}$ Os militares brasileiros vigiavam de perto a dinâmica política uruguaia, enquanto faziam planos de invasão. Segundo o brigadeiro Burger, se os tupamaros conquistassem o poder, criariam graves problemas ao hemisfério. ${ }^{21}$ Mas também uma vitória eleitoral (e democrática) da esquerda não seria tolerada. A derrota da esquerdista Frente Ampla, em novembro de 1971, desativou a ameaça imediata de invasão: a iniciativa havia sido descartada semanas antes da eleição, diante de previsões que apontavam para tal resultado.

O já mencionado encontro entre Médici e Nixon, nos Estados Unidos, no final do ano de 1971, foi precedido de intensa negociação entre assessores sobre o teor da minuta que deveria pautar a agenda oficial; particularmente, havia questões delicadas quanto às ameaças latentes contra o Ocidente que persistiam na região. O Brasil sugeria vinte e cinco pontos de pauta (vários deles tratando sobre questões de segurança na região), e o ponto XII era especificamente sobre o Uruguai. A contraproposta dos EUA reduziu a pauta sugerida a nove pontos; o VIII era sobre "Problemas Hemisféricos: a) Cuba, Chile, Uruguai." Isto é digno de nota. Praticamente na véspera das eleições uruguaias, os EUA consideraram o país um caso tão preocupante quanto a Cuba de Fidel e o Chile de Allende. O fantasma de uma hipotética vitória da Frente Ampla era avaliado com muito receio. ${ }^{22}$ Posteriormente, na véspera do encontro entre ambos os presidentes, Kissinger alertou Nixon sobre algumas preocupações que Médici certamente colocaria na mesa de negociações, entre as quais a situação da Argentina e da Bolívia, e a preocupação com o crescimento da esquerda no hemisfério, o que era exemplificado com a sobrevivência do governo socialista no Chile, e nos $20 \%$ de votação nacional obtida pela Frente Ampla no Uruguai, acontecida recentemente. ${ }^{23}$

A situação se manteria com poucas variantes nos meses seguintes. Mas, no início de 1973, as preocupações da diplomacia brasileira voltaram a se intensificar. O crescimento eleitoral da Unidad Popular de Allende, em março de 1973 - apesar do feroz boicote aplicado pelos setores que agiam explicitamente com o intuito de desestabilizar o regime democrático -,

\footnotetext{
${ }^{20}$ Apud SCHILLING, op. cit.

${ }^{21}$ CONTREIRAS, Hélio. Militares: confissões: histórias secretas do Brasil. Rio de Janeiro: Mauad, 1998, p. 60.

22 "Memorando secreto do Departamento de Estado para o Assessor de Segurança Nacional Henry Kissinger", 13/11/71. The Nacional Security Archive. Disponível em: http://www.gwu.edu/ nsarchive/NSAEBB/NSAEBB71. Acesso em: 23 fev. 2003.

23 "Memorando secreto de Henry Kissinger ao Presidente Nixon", início de dezembro de 1971. The National Security Archive. Disponível em: http://www.gwu.edu/ nsarchive/NSAEBB/NSAEBB71. Acesso em: 23 fev. 2003.
} 
convenceu a direita extremista de que era necessário apelar para outra estratégia, pois, dentro do marco democrático, o apelo popular de Allende parecia sobreviver a toda e qualquer tentativa de desestabilização. Como se isso não bastasse, importante reviravolta política estava em curso na Argentina; após intensas negociações, abria-se espaço para a legalização do peronismo, a volta de Juan Domingo Perón - liderança histórica desse movimento -, e consagrava-se, eleitoralmente, Héctor Cámpora, instalado à esquerda do espectro político do peronismo. Complementarmente, persistia um governo nacionalista no Peru, e consolidava-se uma importante base legislativa da esquerda uruguaia, fruto do processo eleitoral anterior.

Todos estes fatores recriaram, no governo brasileiro, a perspectiva do avanço de novo cerco hostil. Tudo indica que os dispositivos de alarme soaram em Brasília e em Washington. Em pouco mais de dois meses, um golpe de Estado acabou com a fragilizada democracia uruguaia (junho de 1973), um ensaio golpista atingiria o Chile (o Tancazo, também no mês de junho desse ano) e, finalmente, ocorreria o brutal golpe de estado de 11 de setembro de 1973, com a consequente derrubada do governo da Unidad Popular.

\section{Chove sobre Santiago: o golpe de Estado contra Allende e a presença brasileira}

No dia 11 de setembro de 1973, com o golpe civil-militar deflagrado no Chile, inicia-se neste país o período de dezessete anos do governo ditatorial de Augusto Pinochet, ${ }^{24}$ que contou, desde sua instauração, com o apoio e auxílio da ditadura brasileira em questões materiais, políticas, diplomáticas, militares e policiais. Porém, as preocupações com o Chile iniciaram-se bem antes, especialmente após a posse do presidente socialista Salvador Allende, em novembro de 1970, pois o Brasil "não admitia, em sua vizinhança, experiências de esquerda, que viessem a estimular a chamada subversão e obstaculizar, externamente, a expansão dos seus interesses econômicos". ${ }^{25}$ Com o recrudescimento da repressão interna contra qualquer espécie de oposição, no governo do ditador Emílio Médici (outubro de 1969 a março de 1974), o projeto da "via-chilena ao socialismo", conduzido pela Unidad Popular (UP) atraiu um número importante de perseguidos pela ditadura brasileira, que escolheu o Chile como local de exílio. O Brasil passou a intervir junto a essa comunidade com o

\footnotetext{
24 A Junta Militar constituiu-se formalmente com o Comandante em Chefe do Exército, general Augusto Pinochet Ugarte, o Comandante em Chefe da Armada, almirante José Toribio Merino Castro, o Comandante em Chefe da Força Aérea, general Gustavo Leigh Guzmán e o Diretor Geral de Carabineros, general César Mendoza Durán. Os golpistas, após efetuarem um acordo entre si de rodízio de seus integrantes no comando do país, designaram Augusto Pinochet como o primeiro Presidente da Junta Militar.

${ }^{25}$ BANDEIRA, Luiz Alberto Moniz. Conflito e integração na América do Sul: Brasil, Argentina e Estados Unidos: da Tríplice Aliança ao Mercosul. 3 ed. rev. amp. Rio de Janeiro: Civilização Brasileira, 2010. p. 412.
} 
monitoramento das atividades dos seus exilados, criando uma rede de espionagem com elementos próprios e informantes da polícia chilena, como salienta Teresa Marques: "A colaboração que espiões brasileiros ligados ao SNI receberam dos militares chilenos para atuarem ainda durante o governo Allende já demonstrava uma união das Forças Armadas chilena e brasileira na repressão aos membros de grupos esquerdistas". ${ }^{26}$ Já havia no Chile, portanto, uma articulação anterior ao golpe de Estado entre as forças repressivas.

O monitoramento de brasileiros no Chile pelos Serviços de Inteligência brasileiros pode ser visto na Ordem de Busca No 991/72, emitida pelo DOPS/RS, em Porto Alegre, 20 de novembro de 1972: “JAMES ALEN DA LUZ, condenado a 30 anos de prisão pela Justiça da Aeronáutica, assaltante, subversivo, co-participante do assassinato de HENNING ARTUR BOILESEN, atualmente foragido no Chile, deverá retornar ao Brasil, passando antes pelo URUGUAI". 27

Também os brasileiros exilados nas repúblicas vizinhas e mesmo em outros continentes eram alvo de espionagens, expressando diferentes situações que mereciam atenção especial dos órgãos repressivos. Na Circular No 16/71 da SOPS de Cachoeira do Sul, emitida em $1^{\circ}$ de março de 1971, procede-se à transcrição do Informe $N^{\circ}$ 24/71/DCI/SSP/RS, tratando, neste caso, de pessoas que iriam para o Chile e daí para o Brasil:

\section{VOLTA DE BANIDOS AO BRASIL}

1. $\quad$ Em Set. 70, seis elementos, dentre os dez banidos que ainda residem em ARGEL, declararam pretender regressar ao Brasil. Dos seis apenas (4) quatro foram identificados: APOLONIO DE CARVALHO, LADISLAU DOWDOR, JOSE ARAUJO NOBREGA e JOAQUIM PIRES CERVEIRA.

2. Esses elementos se concentrariam inicialmente no CHILE, onde aguardariam cobertura para ingressar em território brasileiro [...].

3. Os seis elementos citados receberiam recursos do BRASIL, para custeio da viagem ao CHILE, passaportes brasileiros falsificados ser-lhesiam entregues em SANTIAGO. ${ }^{28}$

Outro exemplo é a Ordem de Busca No 580/72, de Porto Alegre, 07 de junho de 1972, onde consta que a Divisão de Busca e Coleta de Informações do DOPS/RS procura mapear a locomoção de Sergio Ribeiro Granja - "Garcia" -, José Julio de Araujo e Ricardo Apgaua "Fernandes", que teriam saído do Chile, passado por Buenos Aires e seguido para o

\footnotetext{
${ }^{26}$ MARQUES, Teresa Cristina Schneider. Militância política e solidariedades transnacionais: a trajetória política dos exilados brasileiros no Chile e na França (1968-1979). Tese (Doutorado em Ciência Política). Porto Alegre: UFRGS, 2009. p. 112.

${ }^{27}$ ARQUIVO HISTÓRICO DO RIO GRANDE DO SUL. Acervo da Luta contra a Ditadura. DOPS / Divisão de Busca e Coleta de Informações / CX - 1.2.1771.23.6.

${ }^{28}$ ARQUIVO HISTÓRICO DO RIO GRANDE DO SUL. Acervo da Luta Contra a Ditadura / Fundo: Secretaria da Segurança Pública / Subfundo: Polícia Civil / Departamento de Polícia do Interior / $20^{\mathrm{a}}$ Região Policial / Delegacia Regional de Cachoeira do Sul /SOPS / CX - 1.2.1459.19.5.
} 
Uruguai. O documento, cujo Assunto é - "Subversivos brasileiros no estrangeiro" - conclui com o "pedido de alertar os órgãos de Segurança quanto sua possível entrada no país, e, isso ocorrendo, prendê-los, informando com urgência o DOPS/RS."29

No ano de 1971, agentes do Serviço Nacional de Informações (SNI) atuavam no Chile, visando tanto a desestabilizar o governo da Unidad Popular quanto à obtenção de informações sobre os exilados nesse país. Supostamente, um desses agentes foi o delegado Sérgio Paranhos Fleury, do DOPS/São Paulo, criador dos temidos Esquadrões da Morte que atuavam no Brasil. ${ }^{30}$ A cooperação entre a ditadura brasileira e setores da direita civil ou das forças armadas chilenas não se limitava, por certo, somente à espionagem dos exilados: havia toda uma gama de atividades e ações conjuntas, como no caso dos cursos da Escola Superior de Guerra, reiniciados no Brasil em 1965, e que perduraram até o ano de 1973, quando da criação da Escola Nacional de Informações (EsNI), instituição que assumiu a responsabilidade pela formação de novos quadros das forças de segurança do Brasil e da região. Nesta, os oficiais aprendiam - além dos conteúdos próprios às suas funções - línguas estrangeiras, ideologia política e história, sendo que um dos alunos considerado mais "brilhante" que estudou na EsNI foi o chileno Osvaldo Enrique Romo Mena, ${ }^{31}$ torturador e membro da futura Dirección de Inteligencia Nacional (DINA). A promoção de conferências bilaterais e a troca de materiais também fazia parte da ação de colaboração, como no que concerne, pontualmente, conforme Krischke, ao "Dicionário de Termos e Expressões, Nomes e Siglas utilizados pelos Subversivos Terroristas", elaborado por Edsel Magnotti - oficial de polícia brasileiro -, e encontrado no Arquivo do Terror (no Paraguai). ${ }^{32}$

Como vimos, a preocupação com a desestabilização do governo da UP e a derrocada de Allende era uma constante, especialmente com o recrudescimento das tentativas golpistas, durante o ano de 1972, com a mobilização dos grêmios patronais e dos setores políticos de oposição ao governo, e com a vitória dos candidatos da Unidad Popular nas eleições parlamentares de março de 1973, ocasião em que os setores oposicionistas desistiram definitivamente de um "golpe branco".

\footnotetext{
${ }^{29}$ ARQUIVO HISTÓRICO DO RIO GRANDE DO SUL. Acervo da Luta contra a Ditadura. DOPS / Divisão de Busca e Coleta de Informações / CX - 1.2.1664.21.6.

${ }^{30}$ KRISCHKE, Jair. "Brasil: el enlace". Espacios para la Verdad, la Justicia y la Memoria. Informe Especial Operación Condor. Instituto Espacio para la Memoria, v. 2, n. 2, Buenos Aires, sep. 2009. p. 39.

${ }^{31}$ Informante da polícia chilena, foi contratado pela Dirección de Inteligencia Nacional (DINA), ficando alocado na seção Halcón I da Brigada Caupolicán, encarregada do extermínio do Movimiento de Izquierda Revolucionaria (MIR). Fugiu para o Brasil em 16 de outubro de 1975, com o auxílio de uma rede controlada, ao que tudo indica, pelo Comando Conjunto chileno. Encontrado em 1992, foi extraditado para o Chile.

${ }^{32}$ KRISCHKE, op.cit., p. 38.
} 
Conforme Moniz Bandeira, "o general Orlando Geisel, ministro da Guerra no governo Garrastazu Médici, avisara ao Embaixador do Paraguai no Brasil que cedo o Chile cairia 'em mãos dos militares"', evidenciando, com isso, o conhecimento, por parte do Brasil, da conspiração. Acrescenta, ainda, que Edward Korry, Embaixador dos Estados Unidos em Santiago entre 1967 e 1971, afirmou, em 1977, no Comitê de Relações Exteriores do Senado dos EUA, que o “"real apoio técnico e psicológico' ao coup d’État 'veio do governo militar do Brasil'", 33 Por sua vez, Nathaniel Davis, sucessor de Korry na Embaixada dos Estados Unidos em Santiago (entre novembro de 1971 a final do ano de 1973), informa que o Embaixador do Brasil nos Estados Unidos - Antônio Castro da Câmara Canto, considerado o "Quinto Homem" da Junta Militar - sugeriu-lhe, em março de 1973, que aderisse a um plano de coordenação entre as duas Embaixadas, visando unir esforços para pôr fim ao governo Allende. ${ }^{34}$ Câmara Canto, que fora designado para ocupar esse cargo no Chile, entre 1968 e 1975, estabeleceu relações com altos membros do Exército e da Marinha, e asilou na Embaixada brasileira, em junho de 1973, integrantes do grupo paramilitar Patria y Libertad, após o Tancazo, tentativa militar frustrada de deposição do governo da UP. ${ }^{35}$

A participação civil foi, também, ativa, com empresários brasileiros fornecendo recursos financeiros para a efetivação do golpe. Conforme Moniz Bandeira foram enviados vários carregamentos de armas e munições, entre os anos de 1972 e 1973, pelo Porto de Santos, com destino a Valparaiso. O armamento ia camuflado em caixas de maquinaria agrícola e de outros produtos, importados pela firma do senador Pedro Ibáñez Ojeda, ${ }^{36}$ a fim de abastecer a organização paramilitar chilena Patria y Libertad. ${ }^{37}$ Outro caminho utilizado para contrabandear as armas era a Bolívia do general Hugo Banzer, cujo governo "permitiu o contrabando de armamentos, através de seu território, para os militares chilenos que conspiravam contra o governo de Allende, em bases instaladas por empresários americanobrasileiros". ${ }^{38}$ Marlise Simmons, em reportagem publicada no Washington Post, em janeiro de

\footnotetext{
${ }^{33}$ BANDEIRA, op. cit., p. 414.

${ }^{34}$ DAVIS, Nathaniel. Os dois últimos anos de Salvador Allende. Rio de Janeiro: Civilização Brasileira, 1990. p. 374.

${ }^{35}$ SADER, Emir. "Brasil patrocinou golpe de Pinochet em 1973, no Chile". Carta Maior, 5 ago. 2003. Disponível em: http://www.cartamaior.com.br/?/Editoria/Sem-editoria/Brasil-patrocinou-golpe-de-Pinochet-em1973-no-Chile/27/356. Dentre as amizades estabelecidas por Câmara Canto pode-se destacar Sergio Arellano Starck, Álvaro Puga, Gustavo Leigh, Toribio Merino e Herman Brady.

${ }^{36}$ Pedro Ibáñez Ojeda, senador em 1961 pela Tercera Agrupación Provincial “Aconcagua y Valparaíso”, se incorporou, em 1966, ao Partido Nacional (PN), que ajudou a organizar, e pelo qual foi reeleito pelo período de 1969-1977. Foi membro do PN até 1973, quando, após o golpe, este partido se autodissolveu.

${ }^{37}$ BANDEIRA, op. cit., p. 414.

${ }^{38}$ BANDEIRA, Luiz Alberto Moniz. Fórmula para o caos: a derrubada de Salvador Allende 1970-1973. Rio de Janeiro: Civilização Brasileira, 2008. p. 224. Com o auxílio do Brasil no golpe na Bolívia contra o general Torres, em agosto de 1971, o Chile de Allende perdeu um apoio importante, pois a ditadura Banzer facilitou a
} 
1994, na qual entrevistou empresários vinculados ao Instituto de Pesquisas e Estudos Sociais (IPES), informa que o setor privado teve um papel extremamente importante nos golpes do Brasil e do Chile, e que os empresários brasileiros que conspiraram para a queda do presidente João Goulart, em 1964, foram os mesmos que aconselharam a direita chilena de como lidar com o presidente "marxista" Allende. ${ }^{39}$ De fato, Simmons aponta a troca de informações em círculos empresariais, logo após a vitória eleitoral de Allende. Segundo ela, integrantes do brasileiro Instituto de Pesquisas e Estudos Sociais transmitiram aos empresários chilenos a metodologia de desestabilização desenvolvida pelos setores civis antijanguistas. Assim, foram repassadas técnicas para a criação de caos político e econômico, a difusão do medo ao comunismo junto aos setores populares, o bloqueio legislativo aos esforços da esquerda parlamentar, a organização de manifestações de massa, e, em última instância, o recurso ao terrorismo. Com recomendação do IPES foi fundado, no Chile, o Centro para el Estudio de la Opinión Pública (CEOP), por associações econômicas de industriais e grandes proprietários de terra. Esse instituto se converteu em fonte de estratégia grevista e de lockauts contra as iniciativas governamentais, bem como centro de rumores (guerra psicossocial) e articulação de setores civis anticomunistas e de extrema direita. ${ }^{40}$

Felipe Agüero, ao se questionar sobre as responsabilidades civis em um regime militar, faz uma aproximação entre as ditaduras do Chile e do Brasil. Para o autor, esses dois regimes conseguiram certo nível de institucionalização, ao disporem de regras internas mais ou menos claras acerca de funções e procedimentos para os atores envolvidos, isto sendo resultado, em boa medida, do apoio e colaboração organizada de importantes forças civis. Agüero menciona o fato de o Brasil ter um partido oficial que reagrupava diversos setores das elites sociais e econômicas, expressando uma poderosa aliança política entre essas elites, a tecnocracia e os militares. Já no Chile, o autor aponta que a institucionalização da ditadura foi facilitada pelo apoio irrestrito dado pelas forças de direita que incitaram o golpe de Estado, fator expresso na decisão do Partido Nacional em se autodissolver após o golpe, a fim de deixar completa liberdade de ação para a Junta Militar, uma vez seus objetivos já terem se cumprido. Agüero ressalta que no Chile, como no Brasil, diversas forças da política e da sociedade civil estabeleceram uma aliança com as Forças Armadas para conseguir uma reorganização autoritária do sistema político, destacando-se as grandes associações de

infiltração de recursos variados para os golpistas chilenos, desde armas e munições, passando por esconderijos para agentes da repressão na faixa de fronteira, até oferecimento de asilo para membros de organizações de extrema-direita que necessitassem sair do país.

${ }^{39}$ SIMMONS, Marlise apud DAVIS, op. cit., p. 373.

${ }^{40}$ CASTRO MARTÍNEZ, op. cit., p. 163. 
Outros Tempos, vol. 10, n.16, 2013 p. 229-255. ISSN:1808-8031

empresários industriais e agrícolas, organizações profissionais e os meios de comunicação. Para o autor, essa forte participação civil de apoio e legitimidade à ditadura resultou, em grande medida, da ação da direita politicamente organizada na gestação do golpe, e no posterior transpasso dessas lealdades à ditadura instaurada. ${ }^{41}$

Nesse contexto, a presença dos exilados no Chile foi duramente questionada por ambos os países. Pelo lado do Brasil, conforme Teresa Marques, houve acusações contra o governo de Allende por "permitir que os asilados brasileiros no Chile estivessem divulgando 'declarações ofensivas' ao governo brasileiro através da imprensa local”. Curiosamente, o inverso também ocorria, pois Allende denunciava a campanha de difamação contra seu governo promovida pela imprensa brasileira. ${ }^{42}$ Porém, no Chile as críticas contra a presença de estrangeiros, de modo amplo, eram dirigidas à condução política, tida como errônea, do governo da Unidad Popular. Verónica Ortiz de Zárate ressalta a análise da situação política feita pelo Ex-general Alfredo Canales, o qual entendia que essa orientação conduziria, inevitavelmente, ao avanço do "comunismo", principalmente após as eleições parlamentares de 1973, nas quais a Unidad Popular saiu vitoriosa. Canales, reivindicando o tema da segurança nacional, salientou que esta tinha que se dar, enquanto proteção adequada ao território nacional, nas frentes interna e externa. Nesta última, o Ex-general sustentava que o governo "marxista" havia colocado o Chile em situação difícil com seus vizinhos latinoamericanos, ao desenvolver uma política "sectária" internacional, aproximando-se da órbita soviética e rompendo com o alinhamento com o Ocidente, considerado como o "Bloco Natural" que corresponderia ao Chile. Conforme Canales tais questões deveriam ser prontamente resolvidas, pois - "La presencia y actividades de 'millares de estranjeros' y de 'extremistas' asilados en nuestro territorio comprometen nuestras relaciones con países paralimítrofes", isto ocorrendo "por la contradictoria política comunista de atacar a los militares que gobiernan fuera". 43

Efetivado o golpe, em 11 de setembro de 1973, houve apoio imediato por parte do Brasil, com a tomada de ações nos campos político, econômico, diplomático e repressivo, ficando a coordenação das ações de apoio à nova ditadura a cargo do Embaixador brasileiro

\footnotetext{
${ }^{41}$ AGÜERO, Felipe. "Los civiles (la derecha) en la represión”. In: VILLAGRÁN, Fernando el al. Represión en dictadura: el papel de los civiles. Santiago de Chile: LOM, 2005. p. 30-41.

${ }^{42}$ MARQUES, op. cit., p. 112-113.

${ }^{43}$ ORTIZ DE ZÁRATE, Verónica Valdivia. El golpe después del golpe: Leigh vs. Pinochet. Chile 1960-1980. Santiago de Chile: LOM, 2003. p. 80-81. O general Alfredo Canales foi um dos participantes, no ano de 1972 , do "Plan Marzo", que tinha, dentre outros objetivos, o assalto ao La Moneda e o assassinato de Salvador Allende, conspiração essa que foi descoberta e malograda. Canales não foi afastado, mas somente deslocado para um posto menor. Neste mesmo ano, Canales participou do "Plan Septiembre", outro complô para derrubar o governo de Allende, quando então passou a retiro.
} 
Câmara Canto. ${ }^{44}$ Nesse sentido, surpreende o silêncio da imprensa brasileira em relação aos interesses do Brasil no Chile. Por exemplo, o "Jornal do Brasil" publicou um caderno especial, no dia 12 de setembro, com o título "Tudo sobre a queda de Allende", pretendendo que este fosse o início de uma série (Edições Jornal do Brasil). Tratava-se de uma compilação de sessenta e quatro páginas, contendo notícias publicadas durante os três anos de governo da Unidad Popular (em realidade, desde o processo eleitoral em que surgira como força política vencedora), e mais um dossiê informativo sobre o Chile e o cenário político do governo Allende. Também continha fotos, mapas e quadros estatísticos. Cada matéria era precedida de uma pequena apresentação da sua origem, jornalista envolvido, ou do jornal da qual fora adquirida. Entretanto, este enorme esforço jornalístico vinha marcado pela ausência, "muito perceptível", de qualquer referência à atuação ou posicionamento do Brasil nesse processo. De fato, não há nenhuma menção aos interesses geopolíticos e políticos do país, nem da mediação da Embaixada brasileira e do Itamaraty no transcorrer da crise que deflagrou o golpe de Estado.

No que diz respeito às ações políticas, Moniz Bandeira relata que os Estados Unidos retardaram o reconhecimento da Junta Militar instaurada, pois o Embaixador estadunidense em Brasília, John H. Crimmins, procurou o chanceler Mário Gibson Barbosa, em 14 de setembro, dizendo-lhe que o seu governo "se inclinava favoravelmente" à Junta Militar, mas que aguardaria o reconhecimento de outros países, como a Grã-Bretanha. Entretanto, a Junta Militar foi reconhecida pelos Estados Unidos somente no dia 24 de setembro, após a União Soviética, República Democrática Alemã e Bulgária romperem as relações diplomáticas com o Chile. ${ }^{45}$

Quanto ao reconhecimento brasileiro, Moniz Bandeira informa que já no dia 12 de setembro, Augusto Pinochet, agora na condição de Jefe de la Junta Militar, convidou o coronel Walter Mesquita de Siqueira, attaché militar na Embaixada brasileira, para conversar, dizendo-lhe que gostaria que fosse o Brasil o primeiro país a reconhecer a Junta Militar. Em decorrência disso, o Embaixador Câmara Canto solicitou ao Itamaraty uma autorização

\footnotetext{
${ }^{44}$ A "Folha de São Paulo" de 12 de setembro informava que o governo brasileiro acompanhou os desdobramentos dos acontecimentos através do Itamaraty (o qual se manteve em contato permanente com a Embaixada em Santiago). Entretanto, teria informado que não se pronunciaria a respeito. $\mathrm{O}$ jornal afirmava, ainda, que a crise chilena ocorreu em um momento de recuperação das relações entre ambos os países, após o esfriamento das mesmas, no início do governo Allende, em função da sua orientação marxista. "Folha de São Paulo", 12 set. 1973, p. 3. De forma mais discreta, mas na mesma linha, o jornal "Correio do Povo" informava que o Brasil acompanhava os fatos e, de forma reservada, aguardava o desfecho. "Correio do Povo", 12 set. 1973. O "Estado de São Paulo", também em sua edição de 12 de setembro, mantinha a mesma diretriz: "Brasil acompanha e mantém silêncio".

${ }^{45}$ BANDEIRA, op. cit., p. 552.
} 
urgente para reconhecer o novo governo do Chile, visto isto ser do "máximo interesse" das autoridades chilenas, a fim de fortalecer sua situação. A resposta foi dada a Câmara Canto pelo chanceler Mário Gibson Barbosa ainda nesse primeiro dia posterior ao golpe, dizendolhe que procurasse o general Pinochet para lhe comunicar que o Brasil estava pronto a reconhecer o novo governo, bem como "prestar toda a assistência possível” que viesse a ser solicitada. À noite desse dia 12 de setembro, após falar com o almirante Ismael Huerta designado Ministro de Relaciones Exteriores -, o Embaixador brasileiro informou ao Itamaraty que a Junta Militar agradeceria se o reconhecimento "fosse feito de imediato". No entanto, a fim de não tomar uma decisão "intempestiva e passível de crítica", o governo brasileiro exigiu três "formalidades mínimas": tornar público o controle efetivo do território; divulgar a constituição do governo com o nome de cada ministro e de cada pasta; garantir o respeito aos compromissos internacionais. Gibson Barbosa informava às autoridades chilenas que isso deveria ser feito o quanto antes, pois o governo brasileiro gostaria de reconhecer a Junta Militar nesse mesmo dia 12 de setembro. ${ }^{46}$ Foi assim que esta encaminhou informação esclarecedora, desde o seu ponto de vista, sobre os acontecimentos recentes no país transandino e a atitude patriótica das Forças Armadas. ${ }^{47}$ O jornal "Correio do Povo" divulgou essa iniciativa em matéria encabeçada pela manchete "Mensagem ao Itamaraty: Junta Militar expõe os motivos que a levaram a depor Allende". A seguir, dando continuidade a essa intensa troca de contatos diplomáticos, o jornal mostrava o desdobramento imediato que produzira o esclarecimento chileno junto às autoridades brasileiras. O resultado dessas negociações estava implícito no teor da mensagem do Itamaraty, publicada no dia 14 e que se referia ao pedido do novo regime chileno:

Comunicado do Itamaraty em 13-9-1973.

A Embaixada do Brasil em Santiago recebeu, com data de 12 do corrente, nota da Chancelaria Chilena, comunicando a composição do novo Governo do Chile, participando que este exerce absoluto controle sobre todo o território nacional e que se empenhará em respeitar as obrigações internacionais do País. Na mesma comunicação, a Chancelaria manifestou o desejo do seu Governo de continuar a manter as melhores relações de amizade com o Governo Brasileiro.

O Embaixador do Brasil em Santiago foi autorizado, nesta data, a acusar o recebimento dessa nota e manifestar o desejo do Governo Brasileiro, de acordo com os tradicionais laços de amizade que unem os dois países, de manter as melhores relações com o Governo Chileno. ${ }^{48}$

\footnotetext{
${ }^{46}$ BANDEIRA, op. cit., p. 553.

47 Além de informar a mudança de Embaixador, a nota oficial do novo regime chileno apresentava um conjunto de argumentos (recorrentes aos fatos que haviam marcado o processo de deterioração e o clima golpista que vivia o país desde alguns meses) para justificar a interrupção do governo Allende, acusado de desrespeitar as liberdades de expressão, de ensino e de não dar uma vida digna aos chilenos.

${ }^{48}$ Correio do Povo, 14 set. 1973.
} 
Esta mensagem do Itamaraty estava defasada no próprio jornal, fato demonstrado na mesma edição do dia 14, com outra notícia encabeçada pela manchete "O Itamaraty reconhece e indica normalização". Era dito, assim, que o Brasil reconhecia o novo governo chileno, através da sua Embaixada em Santiago. Considerando que o Itamaraty agia sempre com muita cautela, o jornal concluía que a situação no Chile devia estar bem definida. ${ }^{49}$

No que se refere ao campo econômico, a ajuda provinda do Brasil foi inestimável, pois Câmara Canto já havia advertido em seu contato com o chanceler Gibson Barbosa, no dia 12 de setembro, que faltavam medicamentos e mantimentos. A contribuição brasileira enviada pelos aviões da Força Aérea Brasileira foi a primeira "ajuda humanitária" que a Junta recebeu, desembarcando em Santiago não somente os itens aludidos pelo Embaixador, num montante de vinte toneladas, mas também agentes das Forças Armadas e de Segurança para auxiliar seus colegas chilenos. De acordo com Moniz Bandeira, na segunda viagem aérea - que foi acompanhada pelo coronel Hermán Rojas, attaché da Fuerza Aerea de Chile no Brasil -foram transportadas cinco mil toneladas de arroz e açúcar e trinta toneladas de medicamentos, entre os quais adrenalina, água oxigenada, aspiceme, ataduras e atropinas. ${ }^{50}$

O Embaixador brasileiro, conforme Emir Sader, também se valeu de contatos que tinha no Banco de São Paulo para obter um crédito de cem milhões de dólares para o Chile junto ao Banco Central, constituindo-se esse no primeiro dinheiro que a Junta recebeu, ${ }^{51}$ comprometendo-se essa instituição financeira a entregar, posteriormente, um crédito de mais duzentos milhões de dólares. Moniz Bandeira chama a atenção para o fato de que após o golpe ocorreu o regresso de muitos empresários chilenos que haviam se estabelecido em São Paulo durante o governo de Salvador Allende, pois a afinidade entre as duas ditaduras abriu possibilidades maiores de negócios: “Após o 11 de setembro, até material bélico - tanquetas fabricadas pela Engesa, caminhões leves, da General Motors, e outros itens - as Forças Armadas chilenas e Carabineiros pretendiam adquirir no Brasil, bem como equipamentos para a FACH". 52

No campo repressivo, o auxílio policial e militar do Brasil foi imediato, constituindo-se os monitoramentos e seguimentos efetuados no governo democrático da Unidad Popular em um facilitador da tarefa a ser executada em prol dos "interesses nacionais", pois muitos “inimigos" já estavam identificados e localizados. Como afirma

\footnotetext{
${ }^{49} \mathrm{O}$ jornal repercutia as afirmações do novo Embaixador chileno no Brasil, que garantia que a situação do país era de estabilidade e que não eram procedentes os rumores sobre a existência de focos de resistência de militares legalistas e organizações sindicais. Correio do Povo, 14 set. 1973.

${ }^{50}$ BANDEIRA, 2008, op. cit., p. 558

${ }^{51}$ SADER, op. cit.

${ }^{52}$ BANDEIRA, 2008, op. cit., p. 559. FACH: Fuerza Aerea de Chile.
} 
Pascale Bonnefoy Miralles: "Los brasileños [...] fueron aún más generosos. No sólo habían prestado su embajada para reuniones entre los golpistas chilenos, sino también, desde antes del golpe, había recibido a varios oficiales chilenos para instruirles en técnicas de interrogatorio." ${ }^{53} \mathrm{Na}$ prática, os repressores brasileiros que se haviam deslocado até o Chile, sabiam quem procurar. "No fue casualidad que en los primeros días del golpe de Pinochet, más de cien brasileños que estaban refugiados en Chile, bajo protección de Naciones Unidas, fueron detenidos y llevados al Estadio Nacional", ${ }^{54}$ onde foram interrogados e torturados, havendo, inclusive, brasileiros mortos neste local, que funcionou como campo de concentração a céu aberto entre setembro e novembro de $1973 .{ }^{55}$

Imediatamente após o golpe se expressaram as convicções do general Alfredo Canales, antes aludidas, pois a investida contra os "terroristas" estrangeiros, agentes do “comunismo internacional”, foi brutal. Já no dia 12 de setembro, a Junta Militar, por meio do Bando $N^{o} 24$, dispunha a entrega de armas às Forças Armadas e Carabineros daqueles que estivessem opondo resistência armada ao novo Governo, sendo a punição para os que insistissem nessa posição "suicida e irresponsável” o fuzilamento no ato. Também nesse mesmo dia, ditou-se o Bando $N^{o} 26$ - Comunicación sobre las Actividades de las FF.AA. el 11 y 12 de septiembre de 1973 -, tornando público as principais atividades realizadas pelas Forças Armadas e Carabineros nos primeiros dias após o golpe, destacando a "Detención de numerosos extremistas extranjeros armados". 56

O número de cidadãos brasileiros em situação irregular no momento do Golpe era de 1.297, segundo fontes militares, junto com quase doze mil outros estrangeiros (principalmente bolivianos, uruguaios, argentinos, cubanos e mexicanos) em condições semelhantes. A propaganda desestabilizadora dos meios de comunicação vinculados aos setores golpistas ressaltava que os estrangeiros irregulares eram parte de um temível exército

\footnotetext{
${ }^{53}$ BONNEFOY MIRALLES, Pascale. Terrorismo de Estadio: prisioneros de guerra en un campo de deportes. Santiago: Chile-América: CESOC, 2005. p.119.

${ }^{54}$ KRISCHKE, op. cit., p. 40.

${ }^{55}$ Conforme estimativas da Cruz Vermelha Internacional, o Estadio Nacional, somente no dia 22 de setembro de 1973 chegou a ter cerca de 7.000 detidos; desse número, este organismo estima que entre 200 a 300 pessoas eram estrangeiros de diversas nacionalidades. Os homens passavam a maior parte do dia nas arquibancadas; as mulheres permaneciam no setor da piscina do Estadio. Outro setor do Estadio - o Velódromo - foi habilitado para efetuar os interrogatórios e torturas. Ver: CHILE - Comisión Nacional de Verdad y Reconciliación Comisión Rettig. v. I, Tomo I. Santiago de Chile: Andros/Corporación Nacional de Reparación y Reconciliación, reedición dic. 1996, p. 115. Também CHILE - Comisión Nacional sobre prisión política y tortura - Informe de la Comisión Nacional sobre Prisión Política y Tortura - Informe Valech, cap. VI - Recintos de Detención, p. 524.

${ }^{56}$ BANDO N 24 y BANDO No 26 de la Junta de Gobierno de las Fuerzas Armadas y Carabineros de Chile - 12 sep. 1973. Disponível em: http://www.archivochile.com/Dictadura militar/html/dic militar_doc junta.html.
} 
guerrilheiro estrangeiro; esta era uma das principais ações psicossociais de justificação e mobilização na campanha contra o governo da Unidad Popular. ${ }^{57}$

Ser estrangeiro no Chile, nos dias que se seguiram aos acontecimentos do dia 11 de setembro, implicou em altíssimo risco de vida. O clima de perseguição xenofóbica e "caça às bruxas", desencadeado pelos setores golpistas, resultou no ativismo de muitos vizinhos que, por colaboracionismo ou por medo, diante da incerteza ante os novos donos do poder, delatavam esquerdistas estrangeiros conhecidos ou levantavam suspeitas infundadas com a única intenção de esclarecer de que lado estavam. ${ }^{58}$ A Junta dava as coordenadas para esse tipo de ação: "No se tendrá compasión con los extremistas extranjeros que han venido a matar chilenos. CIUDADANO: Permanece alerta para descubrirlos y denunciarlos a la autoridad militar más próxima". 59

Entre as medidas de contrainformação disseminadas pela imprensa há notícias como a publicada no La Tercera, no dia 27 de setembro, onde se informa que um "agitador brasileiro" de nome Sergio de Moraes, teria ajudado a construir uma força blindada para os extremistas de esquerda, constituída de vinte e seis tanquetas. ${ }^{60} \mathrm{O}$ uso da guerra psicológica para superdimensionar a ameaça comunista e a participação de agentes estrangeiros foi um fator constante na atuação dos setores golpistas desde a vitória eleitoral de Allende. $\mathrm{O}$ objetivo de dividir, acuar ou mobilizar a população, sobretudo os setores mais conservadores ou desinformados, seria mais fácil de ser alcançado a partir do golpe e do terror disseminado.

Retomando acerca do temor dos estrangeiros acolhidos pela administração Allende, deve-se reforçar o dramatismo da situação por eles experimentada. Jorge Montealegre Iturra, chileno, pertencente à Izquierda Cristiana e detido no Estadio Nacional em setembro de 1973, destaca que "Chile había dejado de ser "el asilo contra la opresión,", ao se referir aos estrangeiros seus companheiros neste centro de detenção. Salientando que todo estrangeiro era considerado suspeito, Montealegre destaca as palavras do então Ministro do Interior, general Óscar Bonilla, em entrevista publicada no jornal El Mercurio, de 17 de setembro desse ano: "No dejaremos piedra sobre piedra hasta expulsar el último estranjero", 61 em uma linha próxima às posturas jingoístas que permeavam grande parte da oficialidade chilena.

\footnotetext{
${ }^{57}$ BONNEFOY MIRALLES, op. cit., p. 109-110.

${ }^{58}$ BONNEFOY MIRALLES, op. cit., p. 110.

${ }^{59}$ Ibid., p. 111.

${ }^{60}$ Ibid., p. 110.

${ }^{61}$ MONTEALEGRE ITURRA, Jorge. Frazadas del Estadio Nacional. Santiago de Chile: LOM, 2003, p. 87 e 85 , respectivamente.
} 
Outros Tempos, vol. 10, n.16, 2013 p. 229-255. ISSN:1808-8031

Os presos de outras nacionalidades foram separados dos chilenos, conforme Montealegre Iturra, fato corroborado pelo testemunho de Adam Schesch, também detido no Estadio Nacional em 14 de setembro de 1973, dizendo que ao ser detido foi separado dos demais, e que os nomes dos estrangeiros foram anotados em um livro especial para eles. ${ }^{62} \mathrm{O}$ depoimento do professor brasileiro Nielsen de Paula Pires também aponta para a existência dessa seleção, com a formação de subgrupos no interior deste conjunto de estrangeiros, ao dizer que estava no Estadio Nacional com um grupo de prisioneiros brasileiros constituído por cinquenta homens e dez mulheres, ${ }^{63}$ que foram levados ao centro do gramado e postos em fila. Aí, os agentes dos serviços de Inteligência brasileira, "munidos de catálogo impresso, com fotos e histórico de cada um, buscaram identificar os prisioneiros". Fica visível no depoimento de Paula Pires todo o trabalho anterior de monitoramento e espionagem realizado, o que se confirma, também, com o testemunho de Fernando Batinga, professor e escritor baiano: "Quando fui interrogado pelos militares chilenos, havia militares brasileiros no local, mais ou menos uns cinco deles, que me olhavam e consultavam álbuns de fotografias". ${ }^{64}$

Entrementes, a notícia de que havia oficiais brasileiros no Estadio Nacional se alastrou, sendo denunciada, dentre outros, por Antoine Blanca, secretário de Relações Internacionais do Partido Socialista Francês, ${ }^{65}$ informação esta que também foi despachada para Washington, em outubro de 1973, pelo serviço de Inteligência da CIA em Santiago. ${ }^{66}$ A organização Anistia Internacional (AI) também recebeu denúncias da presença de repressores brasileiros no Chile, após o golpe, solicitando que lhe entregassem os compatriotas detidos pelas forças golpistas. A delegação da Anistia Internacional que visitou Santiago em novembro de 1973 foi informada da atuação de agentes brasileiros no Estadio Nacional, procurando exilados do seu país nos registros administrativos de entrada de presos políticos. Também soube da realização de um curso de interrogatório, com instrutores brasileiros, nas dependências do Ministério de Defesa. Recebeu, ainda, denúncias de detidos brasileiros que

\footnotetext{
${ }^{62}$ MONTEALEGRE ITURRA, op. cit., p. 86; MEMORIA VIVA. Centros de Detención - Región Metropolitana - Estadio Nacional - Santiago - Depoimento de Adam Schesch. Disponível em: http://www.memoriaviva.com/Centros/00Metropolitana.htm.

${ }^{63}$ Segundo registros do próprio Manuel Contreras, chefe da DINA, o número de brasileiros detidos no Estadio Nacional era de 88 (73 homens e 15 mulheres). A CIA, para o período setembro-novembro de 1973, informa um número diferente: 72. Ver BONNEFOY MIRALLES, op. cit., p. 108.

${ }^{64}$ Depoimentos de Nielsen de Paula Pires e Fernando Batinga de Mendonça, prestados a BANDEIRA, 2008, op. cit., p. 560. Nielsen de Paula Pires assinala que os remédios que tomavam no Estadio Nacional tinham imprimido em seus invólucros “doados pela Marinha de Guerra do Brasil”.

${ }^{65}$ BANDEIRA, op. cit., p. 559-560.

${ }^{66}$ SADER, op. cit.
} 
haviam sido torturados por agentes de seu próprio país. ${ }^{67}$ Moniz Bandeira destaca que o grupo de militares brasileiros era comandado pelo tenente-coronel Cyro Etchgoyen; porém, antes da sua chegada, já operavam os coronéis Walter Mesquita de Siqueiros, attaché do Exército e da Aeronáutica, e Décio Barbosa, do Centro de Informações do Exército, bem como os sargentos do Exército Deoclécio Paulo e José Mileski, do Destacamento de Operações e Informações (DOI) do Rio de Janeiro. ${ }^{68}$

Jorge Montealegre relata que soube da existência de agentes que interrogavam em português por um rapaz brasileiro, negro, de dezessete anos, que estava com ele no Estadio Nacional. Diz que o jovem estava de passagem pelo Chile, e que este tinha certeza de que logo sairia dali, pois não tinha "nada a ver" com política. Uma manhã, o levaram para o Velódromo, de onde regressou desfigurado. Foi então que Montealegre soube:

Lo habían interrogado en su propio idioma, militares brasileños, en una cama metálica electrificada, que luego supimos que le llamaban "parrilla", y que también la habían traído de Brasil. Con razón se decía que la dictadura brasileña asesoraba en los interrogatorios además de donarnos Vitamina C. Nuestro amigo no quería hablar mucho, tenía miedo. Solo estuvo una noche más en nuestro camarín. Lo llamaron al disco negro. No regresó al camarín. Años más tarde vi su foto entre las de otras personas desaparecidas. ${ }^{69}$

Enquanto isso, a situação de terror e pânico expressa em execuções sumárias, prisões e perseguições, se refletia nas Embaixadas, que se converteram em locais de refúgio para pessoas de diferentes nacionalidades. Moniz Bandeira realça que, excetuando as Embaixadas do Brasil e do Uruguai, que cerraram suas portas, as de países latino-americanos, tais como Argentina, México, Venezuela, Equador, Peru, Panamá, bem como as Embaixadas de países europeus - entre as quais a da Suécia, que assumiu a representação de Cuba, França, Itália e Santa Sé - abrigavam milhares de pessoas, estrangeiros e chilenos. ${ }^{70}$

Situação esta que foi monitorada minuciosamente pelo aparato repressivo brasileiro, com o envio de listas extensas onde se indicava quem estava em qual local, muitos deles com o grau de parentesco entre as pessoas e os números de seus documentos de identidade, como consta, por exemplo, na Ordem de Busca Confidencial 840/73, expedida de Porto Alegre em 07 de novembro de 1973, pela Divisão de Busca e Coleta de Informações do

\footnotetext{
${ }^{67}$ Entre outros, foi identificado o chefe da equipe brasileira, Alfredo Poeck. Os detidos contaram que no dia 16 de outubro foram interrogados por militares chilenos sobre seus antecedentes no Brasil. Os repressores brasileiros passavam bilhetinhos com as perguntas a serem feitas. Mas, no dia seguinte, foram eles que assumiram a tarefa da tortura. Amnistía Internacional. "Chile: un informe de Amnistía internacional", apud BONNEFOY MIRALLES, op. cit., p. 121-123.

${ }^{68}$ BANDEIRA, op. cit., p. 560.

${ }^{69}$ MONTEALEGRE ITURRA, op. cit., p. 85-86.

${ }^{70}$ BANDEIRA, op. cit., p. 557.
} 
DOPS/RS, com o título: "Banidos Brasileiros Asilados em Embaixadas". Nela se detalham os nomes de 108 brasileiros que estavam asilados na Embaixada da Argentina em Santiago, e que, por estarem "premidos pela Revolução Chilena", fugindo, poderiam retornar ao Brasil. Também se informa os nomes de nove brasileiros que estão asilados na Embaixada do México em Santiago. A solicitação feita é a de prisão e captura dos nominados e imediata comunicação ao Departamento. ${ }^{71}$

Oportuno é mencionar que a Embaixada do Panamá - na qual o Centro de Informações do Exterior informa que no dia 27 de setembro de 1973 contava com 250 pessoas $^{72}$ - foi uma casa residencial até 11 de setembro de 1973, pertencendo ao sociólogo brasileiro Theotônio dos Santos, asilado com sua família no Chile desde o ano de 1965, que a cedeu para sediar aquela Embaixada, devido à falta de condições de salubridade que ocorreu no local onde ela funcionava, pois eram muitas as pessoas literalmente amontoadas em um local minúsculo. ${ }^{73}$ A Embaixada funcionou na casa deste brasileiro até junho de 1974, quando a DINA a transformou em um centro de tortura, desaparecimento e extermínio, pelo período de agosto a novembro de $1974 .^{74}$

No início de outubro de 1973, o Ministério das Relações Exteriores do Chile já havia concedido cerca de 2.200 salvo-condutos para estrangeiros asilados, solicitados por Embaixadas de países europeus e pelo Alto Comissariado das Nações Unidas para os Refugiados (ACNUR). Conforme Emir Sader, autoridades brasileiras entraram em contato com a Junta Militar chilena, dizendo que, como havia muitos infiltrados do SNI que atuavam junto aos "esquerdistas" brasileiros, vários deles haviam desaparecido no momento do golpe, podendo estar presos, e procedeu-se a uma busca desses agentes a fim de serem retirados do Chile. ${ }^{75}$ Por sua vez, o Embaixador brasileiro Câmara Canto solicitou salvo-conduto para três brasileiros detidos no Estadio Nacional - Antônio Paulo Ferraz, Solange Bastos da Silva e Ricardo de Azevedo. O primeiro era filho de Paulo Ferraz, proprietário do Estaleiro Mauá e

\footnotetext{
${ }^{71}$ ARQUIVO HISTÓRICO DO RIO GRANDE DO SUL. Acervo da Luta contra a Ditadura. DOPS / Divisão de Busca e Coleta de Informações / CX - 1.2.1992.25.7.

72 BANDEIRA, op. cit., p. 577.

${ }^{73}$ Maria do Carmo Brito faz um relato minucioso de como foi o exílio na Embaixada do Panamá, incluindo as ações feitas para a transferência de sua sede para a casa de Theotônio dos Santos, salientando que no prédio original da Embaixada - um pequeno apartamento térreo num prédio de quatro andares - havia mais de 200 pessoas para dividir sessenta metros quadrados. Ver: BRITO, Maria do Carmo. "Embaixada do Panamá". In: FERRER, Eliete (Org.). 68 - A geração que queria mudar o mundo - Relatos. Brasília: Ministério da Justiça / Comissão da Anistia / Projeto Marcas da Memória, 2011. p. 592-598.

${ }^{74}$ A Casa José Domingo Cañas $N^{o} 1367$, como ficou conhecida a residência de Theotônio dos Santos, foi denominada pelos agentes da DINA como Cuartel Ollagüe, sendo usada como local de transição desde o fim do funcionamento do centro de detenção, tortura e desaparecimento Londres 38 até o começo das atividades também clandestinas na Villa Grimaldi.

${ }^{75}$ SADER, op. cit.
} 
estreitamente vinculado ao governo militar no Brasil. ${ }^{76}$ A própria Solange Bastos da Silva, relatando sua prisão no Estadio Nacional, recorda que o vice-cônsul brasileiro foi ao local, por insistência do Adido Naval e mobilizado pelo Centro de Informações da Marinha Brasileira (CENIMAR), em busca do filho de um conhecido armador, que estava ali preso junto com oitenta brasileiros: tratava-se de Antônio Paulo Ferraz. ${ }^{77}$

O drama dos exilados pareceu interminável. Militantes políticos brasileiros, como também uruguaios ou de outros países atingidos por ditaduras ou democracias autoritárias, viram-se totalmente desprotegidos e impelidos a mergulhar em uma clandestinidade onde encontrariam escassas condições de sobrevivência, ou procurar abandonar o país. Dadas as condições geográficas do Chile, a menor distância, mesmo que em condições muito tensas, era acessar as embaixadas. A solidão, o infortúnio e os sotaques conspiravam contra; profunda cautela e dose de sorte foram fundamentais para sobreviver até conseguir um canal seguro para abandonar o país. Um paradoxo muito peculiar se havia desenhado para a comunidade de brasileiros: eram alvo de perseguição por sua condição de estrangeiros ideologicamente alinhados ou próximos das posições do governo derrubado, porém o perigo não vinha somente dos uniformizados golpistas vencedores, mas também da atuação nada discreta de compatriotas enviados desde seu país de origem, não para protegê-los, senão para facilitar a sua identificação e possibilitar sua prisão e os suplícios consequentes.

Diante desta colaboração repressiva tão complexa e multifacetada, sob a sombra dos grandes e silenciosos acordos de cúpula, de suas redes diplomáticas, militares, policiais e empresariais, os perseguidos políticos tiveram enorme dificuldade para recuar de forma organizada. Fichados, localizados seus endereços, distribuídas suas fotos pelas ruas ocupadas, a sobrevivência virou obsessão. O longo braço do poder que os havia reprimido no seu país, atingia, agora, o santuário protetor. O "inimigo interno" devia ser golpeado onde estivesse; inclusive no exterior. A ditadura brasileira colaborou ativamente na construção do oceano de regimes de exceção de segurança nacional na região, ajudando seus "amigos de classe, de ideologia ou de doutrina" na cruzada anticomunista, antirrevolucionária e na defesa dos "valores ocidentais". Simultaneamente, a ditadura brasileira não se esquecia dos seus "subversivos", onde quer que estejam e nas condições concretas que fossem. A sensação de grave ameaça está registrada nos relatos dos sobreviventes daqueles eventos: há um momento de clara percepção de é impossível voltar, sendo necessário abandonar o país ou mergulhar na

\footnotetext{
${ }^{76}$ BANDEIRA, op. cit., p. 557; 577.

${ }^{77}$ BASTOS, Solange. "Eu estive presa no Estadio Nacional do Chile". In: FERRER, op. cit., p. 573-576.
} 
clandestinidade profunda, mas isso em um país que não é o próprio, o que implica em maiores riscos exigidos por essa experiência. Por mais que os registros da memória estejam sujeitos a percalços dos diversos filtros aplicados consciente ou inconscientemente, a aproximação dessas situações rememoradas pelos seus protagonistas é uma forma de humanizar o drama dos perseguidos diante das brutais ações desencadeadas pelo terror de Estado:

[...] Fui me aproximando do portão, caminhando sem sentir os pés, as pernas, sem sentir nada. Dentro de mim fervia violento o instinto de sobrevivência. Só enxergava aquele portão aberto e a embaixada toda cercada por militares e sacos de areia na calçada. Bem no portão, dois soldados, de guarda, com fuzis e metralhadoras.

Caminhava procurando aparentar toda a indiferença possível, sufocando o vulcão interno, consciente de que ou entrava, ou ia para o Estádio Nacional, onde seria morto pelos policiais brasileiros que lá estavam para interrogar e torturar seus compatriotas presos.

Andando no meio da rua, tinha uma certeza absoluta: ou entraria, ou seria baleado, ou preso e morto.

Tinha chegado a hora. Em frente ao portão, explodindo de tensão, todo eriçado, fora de mim qual animal acuado, de súbito desandei em corrida alucinada, impelido pela força injetada pelo desespero, movido pelo instinto. Do meio da rua, quase num pulo alcancei o portão. Os dois soldados de sentinela tiveram um momento de surpresa, de perplexidade, outro de dúvida se me agarrravam ou baleavam. Naquilo já estava junto deles, e na corrida abri os braços derrubando os dois. Sempre correndo, entrei, só parando quando bati na parede da embaixada.

Salvo. Vivo. ${ }^{78}$

Lembrando o desespero do gaúcho João Carlos Bona Garcia, diante da última chance de conseguir refúgio na Embaixada da Argentina, explicitamos um drama que se multiplicou em inúmeras oportunidades e que atingiu um enorme número de cidadãos brasileiros perseguidos até o último rincão do planeta pela coordenação de serviços de segurança e inteligência de vários países, costurada pela lógica da Doutrina de Segurança Nacional.

Independente das acusações envolvendo a participação do governo Médici na queda de Salvador Allende e no fim da experiência da Unidad Popular, a ditadura brasileira sempre procurou afastar de si tal responsabilidade. Isso aconteceu desde cedo. Nesse sentido, o jornal "Correio do Povo", de 14 de setembro de 1973, destacava a irritação de altos funcionários do governo brasileiro diante das acusações de colaboração da administração Médici com os setores golpistas chilenos. Os mesmos consideravam "absurdos e injustificáveis" os comentários que circulavam em certos países, e que apontavam o Brasil

\footnotetext{
${ }^{78}$ BONA GARCÍA, João Carlos; POSENATO, Júlio. Verás que um filho teu não foge à luta. Porto Alegre: Posenato Arte e Cultura, 1989. p. 136.
} 
como país "interessado" ou que havia agido como "colaborador" na deposição de Allende. Seja como for, a Junta Militar chilena recebeu imediato reconhecimento diplomático do Brasil, o que lhe permitiu dispor, desde o início, de apoio político de um dos países mais estratégicos da região.

$\mathrm{Na}$ medida em que se avança na disponibilização de documentos dos arquivos repressivos dos diversos países da região e dos EUA, bem como no cruzamento das informações neles contidas, encontram-se, cada vez mais, os traços e marcas de uma teia de interesses e de uma rede de intercâmbio e colaboração que amalgamaram a aproximação de grupos que possuíam uma mesma base de compreensão do mundo, de valores a defender e de outros a combater. A análise do golpe contra Allende e a instalação e posterior consolidação da ditadura personificada na figura de Augusto Pinochet demonstra que não basta somente uma perspectiva nacional, das raízes internas desses eventos, para a compreensão de processo tão complexo. É fundamental desenvolver uma perspectiva de análise que estabeleça a relação dialética entre fatores internos e externos, muitos deles de cunho regional. Sendo assim, é pertinente considerar interpretações que possibilitam compreender um processo histórico que, em determinado contexto, é marcado por toda uma rede de fluxos e refluxos que emoldura uma lógica de embates, conexões e entrecruzamentos de interesses, resultante da combinação de fatores nacionais, intra-regionais e extra-regionais. Tanto a queda do governo da Unidad Popular quanto a posterior ditadura podem ser explicados a partir de desdobramentos da política interna chilena. No entanto, ganham outra dimensão se devidamente contextualizados em um mundo de Guerra Fria e em um continente marcado pela aguda desigualdade social, Revolução Cubana e aplicação de políticas de contra insurgência. Da mesma forma, a presença brasileira no golpe contra Allende (e no posterior apoio à ditadura Pinochet) é um sinal evidente desse complexo emaranhado de relações que aproximam e tornam aliados certos protagonistas e, em contraposição, identificam outros como inimigos, sejam "inimigos internos", "inimigos internos" exilados ou "inimigos internos" dos aliados e amigos ideológicos, políticos ou de classe, dos países vizinhos.

Através da defesa das orientações da DSN e das premissas essencialistas do anticomunismo da Guerra Fria, um cenário de ditaduras de segurança nacional se expandiu pelo Cone Sul, como aconteceu no Chile. O Brasil, anteriormente, também vinha sendo cenário dessa experiência; e paradigmaticamente a ditadura brasileira, com suas ações "defensivas" e percepções de potenciais ameaças de "cerco", muito contribuiu para a disseminação e consolidação dos regimes repressivos na região, agindo com pretensões geopolíticas e de hegemonia regional, e mantendo, muitas vezes, uma fina sintonia com os 
Outros Tempos, vol. 10, n.16, 2013 p. 229-255. ISSN:1808-8031

interesses estadunidenses na região. O complexo e tumultuado cenário chileno foi laboratório dessas práticas, como também havia ocorrido, recentemente, com a Bolívia e o Uruguai. Embora seja necessário aprofundar pesquisas a esse respeito, sobretudo à luz dos novos documentos disponibilizados, os sinais desse rastro são cada vez mais evidentes. 